J. Clin. Chem. Clin. Biochem.

Vol. 26, 1988, pp. $877-884$

(C) 1988 Walter de Gruyter \& Co.

Berlin · New York

\title{
Automation of the Prothrombin Time Assay on a Centrifugal Analyser Using Two Different Chromogenic Substrate Reagents
}

\author{
By E. H.J. Smeets and J.W.J. van Wersch \\ Haematological Laboratory, De Wever Hospital, Heerlen, The Netherlands
}

(Received June 16/September 8, 1988)

Summary: Methods employing chromogenic substrates for the photometric determination of prothrombin time have several advantages over conventional coagulometric methods. We evaluated the analytical qualities of two recently introduced reagents for the photometric determination of prothrombin time. The assays were performed on a centrifugal analyser. Both reagents showed good precision, even with sample volumes of $10 \mu \mathrm{l}$ or $12 \mu \mathrm{l}$. The stability of the reagents during storage was investigated at $4{ }^{\circ} \mathrm{C}, 25^{\circ} \mathrm{C}$ and $37^{\circ} \mathrm{C}$. The chromogenic reagent, which contains thromboplastin from human placenta, was compared with a coagulometric method, which includes ox-brain thromboplastin: coagulation activities calculated from International Normalized Ratio values showed good correlation and conformity over the whole test range. The other chromogenic reagent contains thromboplastin from rabbit brain; outside the therapeutic range for oral anticoagulation the results obtained with this reagent showed poor agreement with those obtained with the coagulometric method. Both chromogenic reagents were sensitive to reduced concentrations of coagulation factors of the extrinsic pathway and nearly insensitive to low factor IX concentrations. The results of the photometric test paralleled those of the clotting method during oral anticoagulation therapy.

\section{Introduction}

Since its adoption for monitoring oral coagulation therapy, the determination of the prothrombin time introduced by Quick $(1,2)$ has become the most frequently performed test in haemostasis laboratories. In our laboratory $83 \%$ of all requests for coagulation tests require the assay of prothrombin time for therapy control, while in another $4 \%$ the prothrombin time is used for screening coagulation pathology. The Thrombotest ${ }^{\circledR}$, a one-stage coagulometric test for prothrombin time introduced by Owren (3), is widely used for monitoring anticoagulant treatment, because it uses a bovine brain thromboplastin with a high sensitivity to proteins induced by vitamin $\mathrm{K}$ absence (PIVKA); which are produced during treatment with vitamin $K$ antagonists $(4,5)$. However, the develop- ment of synthetic peptides, which serve as specific substrates for particular enzymes of the coagulation system $(6-8)$, has offered attractive possibilities for the introduction of automated photometric assays of the prothrombin time $(9-16)$.

We evaluated the analytical qualities of two recently introduced photometric tests for the measurement of prothrombin time, which we performed on a centrifugal analyser. Secondly, we compared the results of both photometric tests with the Thrombotest ${ }^{\circledR}$ in samples with normal or subnormal coagulation activity, as well as during anticoagulant therapy, and studied the sensitivity to lowered concentrations of coagulation factors. Finally, the possibility of reducing the volumes of sample and reagent was explored. 


\section{Materials and Methods}

\section{Samples}

Venous blood samples, received by the laboratory for monitoring anticoagulant therapy or for screening the coagulation state, were used for the study. We collected 280 samples for comparison of the three tests. Citrated plasma was prepared by centrifugation of nine volumes of freshly drawn blood with one volume of trisodium citrate $(0.109 \mathrm{~mol} / \mathrm{l})$ for $10 \mathrm{~min}(1600 \mathrm{~g})$ at $25^{\circ} \mathrm{C}$. Plasma was used immediately, or stored at $-70^{\circ} \mathrm{C}$ in plastic tubes and thawed with tap water for $5 \mathrm{~min}$ before use. Normal pool plasma was collected from 20 outpatients. Two samples with a prothrombin time deviating more than $3 \mathrm{SD}$ from the mean were excluded. Equal volumes of the remaining 18 samples were mixed and stored in small aliquots at $-70^{\circ} \mathrm{C}$. The prothrombin time of this pool did not differ significantly from the value of a pool of 50 healthy blood donors. Other pool plasmas were mixtures of patient samples selected after assay with the Thrombotest ${ }^{\oplus}$.

\section{Other materials}

Plasmas deficient in factor VII (less than $2 \%$ of normal level), or in factor II, V or IX (each less than $1 \%$ of normal level) were obtained from Merz and Dade (Düdingen, Switzerland); factor X-deficient plasma (less than $1 \%$ of normal level) was from Behringwerke AG (Marburg, FRG).

Precinorm control plasmas were obtained from Boehringer Mannheim GmbH (Mannheim, FRG) and CTS Control plasmas from Behringwerke AG (Marburg, FRG).

\section{Photometric reagents}

We used two recently developed reagents for the photometric determination of prothrombin time. The Chromoquick ${ }^{*}$ reagent (Bebringwerke AG, Marburg, FRG) consists of thromboplastin from human placenta, the chromogenic substrate for thrombin, tosylglycyl- $L$-prolyl- $L$-arginyl-5-amino-2-nitrobenzoic acid isopropylamide chloride $50 \mu \mathrm{mol} / \mathrm{l}$, sodium chloride $50 \mathrm{mmol} / \mathrm{l}$, calcium chloride $5 \mathrm{mmol} / \mathrm{l}$, HEPES buffer $25 \mathrm{mmol} / 1$ and the heparin antagonist hexadimethrin bromide (Polybrene ${ }^{(1)}$ ). The Thromboquant ${ }^{(i)}$ prothrombin time reagent (Boehringer Mannheim GmbH, Mannheim, FRG) consists of calcium thromboplastin from rabbit brain, the chromogenic substrate for thrombin, tosyl-glycyl- $L$-prolyl- $L$-arginyl-p-nitroanilide (Chromozym ${ }^{\text {ts }} \mathrm{TH}$ ) $50 \mu \mathrm{mol} / \mathrm{l}$, calcium chloride $6 \mathrm{mmol} / \mathrm{l}$ and Tris/HCl buffer $100 \mathrm{mmol} / \mathrm{l}, \mathrm{pH} 8.1$.

\section{Principle of the photometric tests}

During a lag phase the extrinsic coagulation system is activated by thromboplastin in the presence of calcium ions, resulting in the generation of thrombin. A chromogenic substrate, which is specific for thrombin, is then hydrolysed with liberation of a chromophore, of which the absorbance is measured at $405 \mathrm{~nm}$. The reaction product is 5-amino-2-nitrobenzoic acid isopropylamide in the Chromoquick test and $p$-nitroanilide in the Thromboquant test. The prothrombin time corresponds to the time elapsed from the start of the reaction until an increase of 0.1 absorbance has been obtained. The fibrinogen concentration can roughly be estimated in the same system by calculating the increase of the absorbance caused by the formation of fibrin, which starts shortly after the hydrolysis of the chromogenic substrate $(13,15)$.

\section{Pcrformance of the photometric tests}

A Cobas $\mathrm{Bio}^{\boxplus}$ centrifugal analyser (Hoffmann-La Roche, Basel, Switzerland) was coupled to an Epson HX-20 calculator in the
Thromboquant method and to a Hewlett Packard HP-85 calculator in the Chromoquick method. The test conditions are given in table 1. Programs for calculation of the results were provided by the reagent manufacturers. The start of the reaction was fixed at $5.5 \mathrm{~s}$ before the time of first reading in the Chromoquick program and at $10 \mathrm{~s}$ in the Thromboquant program. The end of the prothrombin time was assessed by interpolation of the data taken every $10 \mathrm{~s}$. The reagent tube iand cuvette of the Cobas Bio were thermostatically controlled at $37^{\circ} \mathrm{C}$. Between runs the reagent tube was closed to limit evaporation, because an increase in the calcium and buffer concentrations increases the reaction time (17).

Tab. 1. Instrument settings of the Cobas $\mathrm{Bio}^{\oplus}$

\begin{tabular}{lcc}
\hline Parameter Listing & $\begin{array}{c}\text { Chromo- } \\
\text { quick }\end{array}$ & $\begin{array}{c}\text { Thrombo- } \\
\text { quant }\end{array}$ \\
\hline 1 Units & own & own \\
2 Calculation factor & 1000 & 1000 \\
3 Standard 1 conc. & 0 & 0 \\
4 Standard 2 conc. & 0 & 0 \\
5 Standard 3 conc. & 0 & 0 \\
6 Limit & 0 & 0 \\
7 Temperature $\left({ }^{\circ} \mathrm{C}\right)$ & 37.0 & 37.0 \\
8 Type of analysis & 2 & 2 \\
9 Wavelength (nm) & 405 & 405 \\
10 Sample volume $(\mu \mathrm{l})$ & 20 & 12 \\
11 Diluent volume $(\mu \mathrm{l})$ & 5 & 5 \\
12 Reagent volume $(\mu \mathrm{l})$ & 200 & 180 \\
13 Incubation time $(\mathrm{s})$ & 0 & 0 \\
14 Start-reagent volume $(\mu \mathrm{l})$ & 0 & 0 \\
15 Time of first reading $(\mathrm{s})$ & 0.5 & 10.0 \\
16 Time interval $(\mathrm{s})$ & 10 & 10 \\
17 Number of readings & 16 & 16 \\
18 Blanking mode & 1 & 1 \\
19 Printout mode & 3 & 3 \\
\hline
\end{tabular}

\section{Coagulometric assay of prothrombin time}

The coagulometric prothrombin time assay according to Owren $(3,18)$ was performed in whole blood with Thrombotest ${ }^{+\infty}$ reagent (Nycomed AS, Oslo, Norway) on a Lode ${ }^{\text {(i) }}$ coagulometer (Lode Instruments, Groningen, The Netherlands). The reagent contains ox-brain thromboplastin, cephalin and calcium chloride $3.2 \mathrm{mmol} / \mathrm{l}$, and excess factor $\mathrm{V}$ and fibrinogen.

\section{Calculations}

In the coagulometric as well as in the photometric methods the prothrombin ratio (R), International Normalized Ratio (INR) and percentage Thrombotest activity were provided by the calculators. $R$ is the quotient of the prothrombin time measured in a patient sample and in normal pool plasma. INR was calculated from $R$ with the relation INR $=R^{\text {ISI }}$ using the International Sensitivity Index (ISI) stated for the reagent batch (19). The percentage Thrombotest was calculated from the INR with the empirical assessed relation $(20,21)$ INR $=0.8+(20 /$ Thrombotest percentage). The relation between the Thrombotest percentages estimated in patient samples by different methods was calculated by the orthogonal regression analysis of Dening $(22,23)$.

Determination of the stability of photometric reagents

Reagents were kept at $4{ }^{\circ} \mathrm{C}, 25^{\circ} \mathrm{C}$ and $37^{\circ} \mathrm{C}$ and the percentage Thrombotest was determined in freshly thawed CTS Control plasmas after $1,2,4$ and $6 \mathrm{~h}$ storage, then -daily during three days storage at $25^{\circ} \mathrm{C}$ and six days storage at $4{ }^{\circ} \mathrm{C}$. Linear 
regression and standard error of estimate (SEE) were calculated for the dependence of the percentage Thrombotest on the storage time. The limit of stability was defined as the ratio $2 \mathrm{SEE} / \mathrm{b}$, in which $b$ is the regression constant of the relation between the percentage Thrombotest and the storage time.

Determination of the sensitivity of prothrombin time reagents to the concentration of single factors

Plasmas with concentrations of single factors varying from $5 \%$ to $100 \%$ were prepared by mixing one volume of normal pool plasma, which was undiluted or prediluted with Owren's buffer (18), with one volume Owren's buffer and two volumes plasma deficient in a single factor.

\section{Results}

In figure 1 the development of the absorbance in both photometric tests is demonstrated for plasmas with percentage Thrombotest activities varying from $8 \%$ to $55 \%$. In the Chromoquick test the lag time is shorter, the reaction develops faster and the difference of the absorbance is greater than in the Thromboquant test. This is in agreement with the finding of shorter prothrombin time values in the Chromoquick test. The prothrombin time, determined in quadru-
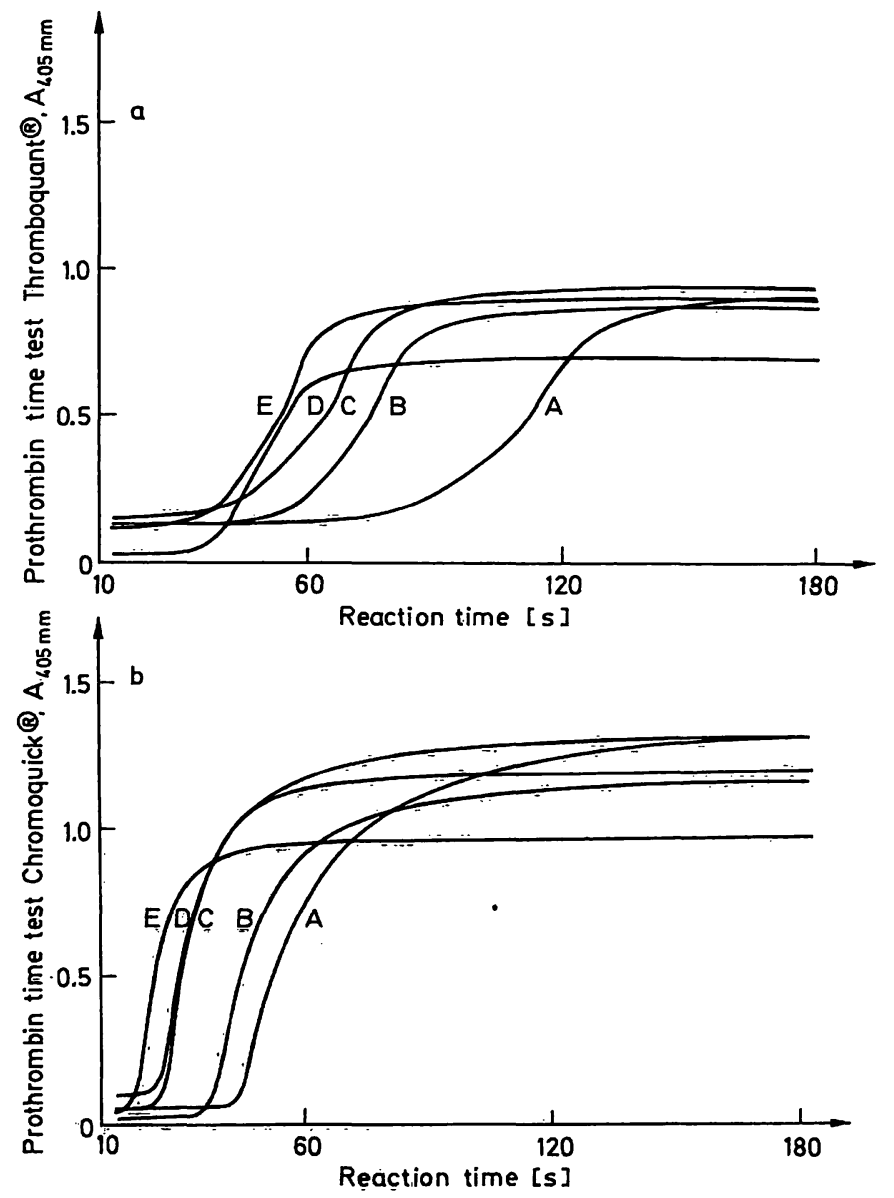

Fig. 1. Recorder profiles of photometric prothrombin time tests in plasmas with various Thrombotest coagulation activities: A: $6 \%$; B: $13 \%$; C: $22 \%$; D: $41 \%$ and E: $55 \%$.

a) Thromboquant ${ }^{(\$)}$

b) Chromoquick $^{\oplus}$ plicate in normal pool plasma, was $21.2 \mathrm{~s}$ in the chromoquick test and $34.5 \mathrm{~s}$ in the Thromboquant test, while it amounted to $36.7 \mathrm{~s}$ in the Thrombotest.

\section{Reproducibility}

The reproducibility of both photometric tests was assessed by multiple determinations in pooled plasma and in lyophilized control plasmas with normal as well as variously prolonged prothrombin time values. Freshly thawed samples were determined on different days for the examination of the between-run variability. The intra- and inter-assay CV for the prothrombin time were $0.3-1.1 \%$ and $0.8-2.0 \%$, respectively, in the Chromoquick tests and $0.8-1.2 \%$, and $1.5-$ $4.2 \%$, respectively, in the Thromboquant tests. The intra- and inter-assay CV for the percentage Thrombotest activity were $0.6-4.7 \%$ and $2.1-11.5 \%$, respectively, in the Chromoquick test and 1.5-4.8\% and $5.5-8.3 \%$, respectively, in the Thromboquant test. Samples with Thrombotest activity in the therapeutic range of oral anticoagulation exhibited much better precision than samples with normal Thrombotest activity (tab. 2 and 3 ).

\section{Stability of reagents}

The stability of the photometric reagents was assessed with CTS Control plasmas, containing normal and subnormal activities, as well as a therapeutic level for anticoagulant therapy. Stability limits of the reagents during storage at $4{ }^{\circ} \mathrm{C}, 25^{\circ} \mathrm{C}$ and $37^{\circ} \mathrm{C}$ are given in table 4. Our findings corresponded with the values stated by the manufacturers for storage at $4{ }^{\circ} \mathrm{C}$. However, we found much lower stability at higher temperatures. On average, the relative decrease of the percentage Thrombotest was $14 \%$ at the stability limits.

We also assayed the relative decline of the measured percentage Thrombotest activity in eight patient plasmas with various Thrombotest activities, while keeping the reagents at $37^{\circ} \mathrm{C}$ in an uncovered container of the Cobas $\mathrm{Bio}^{\circledR}$ analyser for $1 \mathrm{~h}, 2 \mathrm{~h}$ and $4 \mathrm{~h}$, respectively. Under these conditions, the mean relative decline of the Thrombotest percentages was 5\%, $12 \%$ and $30 \%$, respectively, using the Chromoquick test. With the Thromboquant test the mean relative decline was $6 \%, 16 \%$ and $42 \%$, respectively.

\section{Comparison of methods}

Results of the Chromoquick and Thromboquant assays in plasmas were compared with Thrombotest ${ }^{\text {th }}$ results in 280 samples of whole blood from patients undergoing oral anticoagulant therapy or screening 
Tab. 2. Intra- und inter-assay variation of the Thromboquant ${ }^{*}$ test. Freshly thawed samples were estimated twenty times within one run, as well as on twenty different days.

\begin{tabular}{|c|c|c|c|c|c|c|c|c|}
\hline \multirow[t]{3}{*}{ Plasna } & \multicolumn{4}{|c|}{$\begin{array}{l}\text { Prothrombin time } \\
\text { (s) }\end{array}$} & \multicolumn{4}{|c|}{$\begin{array}{l}\text { Thrombotest } \\
\text { coagulation activity (\%) }\end{array}$} \\
\hline & \multicolumn{2}{|c|}{ intra-assay } & \multicolumn{2}{|c|}{ inter-assay } & \multicolumn{2}{|c|}{ intra-assay } & \multicolumn{2}{|c|}{ inter-assay } \\
\hline & mean & $\mathrm{CV}(\%)$ & mean & $\mathrm{CV}(\%)$ & mean & CF $(\%)$ & mean & CV (\%) \\
\hline Pool plasma & 42.0 & 1.2 & 42.3 & 2.8 & 42.2 & 4.8 & 42.0 & 8.3 \\
\hline Pool plasma & 49.6 & 1.2 & 46.4 & 2.8 & 26.1 & 3.5 & 26.5 & 6.8 \\
\hline Pool plasma & 80.2 & 1.0 & 79.8 & 2.6 & 9.7 & 1.5 & 10.1 & 5.5 \\
\hline Precichrom normal & 37.2 & 0.8 & 37.2 & 1.5 & 66.4 & 3.0 & 66.4 & 7.1 \\
\hline Precichrom ${ }^{\star}$ abnormal & 103.0 & 1.0 & 96.8 & 4.2 & 6.5 & 2.2 & 7.2 & 6.8 \\
\hline
\end{tabular}

Tab. 3. Intra- and inter-assay variation of the Chromoquick ${ }^{\text {(i }}$ test. Freshly thawed samples were estimated ten times within one run, as well as on ten different days.

\begin{tabular}{|c|c|c|c|c|c|c|c|c|}
\hline \multirow[t]{3}{*}{ Plasma } & \multicolumn{4}{|c|}{$\begin{array}{l}\text { Prothrombin time } \\
\text { (s) }\end{array}$} & \multicolumn{4}{|c|}{$\begin{array}{l}\text { Thrombotest } \\
\text { coagulation activity (\%) }\end{array}$} \\
\hline & \multicolumn{2}{|c|}{ intra-assay } & \multicolumn{2}{|c|}{ inter-assay } & \multicolumn{2}{|c|}{ intra-assay } & \multicolumn{2}{|c|}{ inter-assay } \\
\hline & mean & CV (\%) & mean & $\mathrm{CV}(\%)$ & mean & CV $(\%)$ & mean & $\mathrm{CV}(\%)$ \\
\hline Pool plasma & 21.9 & 1.1 & 21.8 & 1.2 & 75.0 & 4.7 & 75.3 & 5.0 \\
\hline Pool plasma & 28.7 & 0.7 & 29.7 & 0.9 & 28.6 & 1.6 & 28.5 & 2.1 \\
\hline Pool plasma & 39.6 & 0.3 & 39.8 & 1.4 & 15.8 & 0.6 & 15.7 & 2.7 \\
\hline CTS Control plasma $\mathrm{N}$ & 20.6 & 0.7 & 20.7 & 2.0 & 96.4 & 3.7 & 98.7 & 11.5 \\
\hline CTS Control plasma P1 & 25.2 & 0.5 & 24.9 & 0.8 & 42.4 & 1.5 & 46.4 & 2.5 \\
\hline CTS Control plasma P2 & 57.8 & 0.8 & 57.5 & 1.9 & 8.5 & 1.4 & 8.6 & 4.0 \\
\hline
\end{tabular}

Tab. 4. Stability of the photometric prothrombin time reagents stored at several temperatures. Coagulation activity was determined in CTS control plasmas with normal (N) and subnormal (P1) activity as well as a therapeutic level for anticoagulant treatment (P2). $\triangle \mathrm{A}$ : relative decline of thrombotest coagulation activity at the estimated stability limit (\%); L: estimated stability limit (days or hours); LR: stability limit stated by the manufacturer.

\begin{tabular}{|c|c|c|c|c|c|c|c|c|c|}
\hline \multirow{2}{*}{$\begin{array}{l}\text { Storage } \\
\text { temperature }\end{array}$} & \multirow[t]{2}{*}{ Plasma } & \multicolumn{4}{|c|}{ Chromoquick $^{\oplus}$} & \multicolumn{4}{|c|}{ Thromboquant ${ }^{\circledR}$} \\
\hline & & $\Delta \mathrm{A}$ & $\mathrm{L}$ & $\overline{\mathbf{L}}$ & LR & $\overline{\Delta \mathrm{A}}$ & $\mathrm{L}$ & $\overline{\mathrm{L}}$ & LR \\
\hline $4^{\circ} \mathrm{C}$ & $\begin{array}{l}\mathrm{N} \\
\mathrm{P} 1 \\
\mathrm{P} 2 \\
\end{array}$ & $\begin{array}{l}23.9 \% \\
16.2 \% \\
10.7 \% \\
\end{array}$ & $\begin{array}{l}6.6 \mathrm{~d} \\
8.1 \mathrm{~d} \\
6.0 \mathrm{~d}\end{array}$ & $7 d$ & $7 d$ & $\begin{array}{r}12.1 \% \\
14.9 \% \\
5.7 \%\end{array}$ & $\begin{array}{l}1.8 \mathrm{~d} \\
4.8 \mathrm{~d} \\
7.2 \mathrm{~d}\end{array}$ & $5 \mathrm{~d}$ & $5 d$ \\
\hline $25^{\circ} \mathrm{C}$ & $\begin{array}{l}\mathrm{N} \\
\mathrm{P} 1 \\
\mathrm{P} 2 \\
\end{array}$ & $\begin{array}{r}20.3 \% \\
22.9 \% \\
6.7 \% \\
\end{array}$ & $\begin{array}{l}31 \mathrm{~h} \\
39 \mathrm{~h} \\
22 \mathrm{~h}\end{array}$ & $31 \mathrm{~h}$ & $48 \mathrm{~h}$ & $\begin{array}{r}19.0 \% \\
13.8 \% \\
6.1 \%\end{array}$ & $\begin{array}{r}11.6 \mathrm{~h} \\
9.7 \mathrm{~h} \\
7.7 \mathrm{~h}\end{array}$ & $10 \mathrm{~h}$ & $24 \mathrm{~h}$ \\
\hline $37^{\circ} \mathrm{C}$ & $\begin{array}{l}\mathrm{N} \\
\mathrm{P} 1 \\
\mathrm{P} 2\end{array}$ & $\begin{array}{r}14.2 \% \\
9.6 \% \\
5.5 \% \\
\end{array}$ & $\begin{array}{l}2.2 \mathrm{~h} \\
1.7 \mathrm{~h} \\
2.4 \mathrm{~h}\end{array}$ & $2 \mathrm{~h}$ & $8 \mathrm{~h}$ & $\begin{array}{r}20.3 \% \\
6.2 \% \\
4.7 \%\end{array}$ & $\begin{array}{l}4.4 \mathrm{~h} \\
1.6 \mathrm{~h} \\
4.6 \mathrm{~h}\end{array}$ & $4 \mathrm{~h}$ & $8 \mathrm{~h}$ \\
\hline
\end{tabular}

for their coagulation state (fig. 2 and tab. 5). The correlation between the photometric tests and Thrombotest $^{\circledR}$ was better in the therapeutic range than in subnormal or normal ranges. The Chromoquick test correlated better with the Thrombotest ${ }^{\oplus 1}$ than the Thromboquant in all activity ranges. Thromboquant correlated rather poorly with the Thrombotest ${ }^{\circledR 4}$ in subnormal and normal ranges. The regression constant of the relation between Chromoquick and Thrombotest ${ }^{\text {(i) }}$ results amounted to 1.58 for the whole activity range and increased from 1.30 in the thera- peutic range to 3.27 in the normal range. Unlike the computerized program for Thromboquant, the standard program for Chromoquck included $5 \mathrm{~s}$ mixing of sample and reagent in the prothrombin time. In another collection of 152 samples, we therefore compared the Thrombotest ${ }^{\oplus}$ results with Chromoquick results, using a modified computer program, in which the start of the prothrombin time was fixed at $0.5 \mathrm{~s}$ before the first reading, instead of $5.5 \mathrm{~s}$. This improved the regression constant considerably. The regression constant of the relation between Throm- 

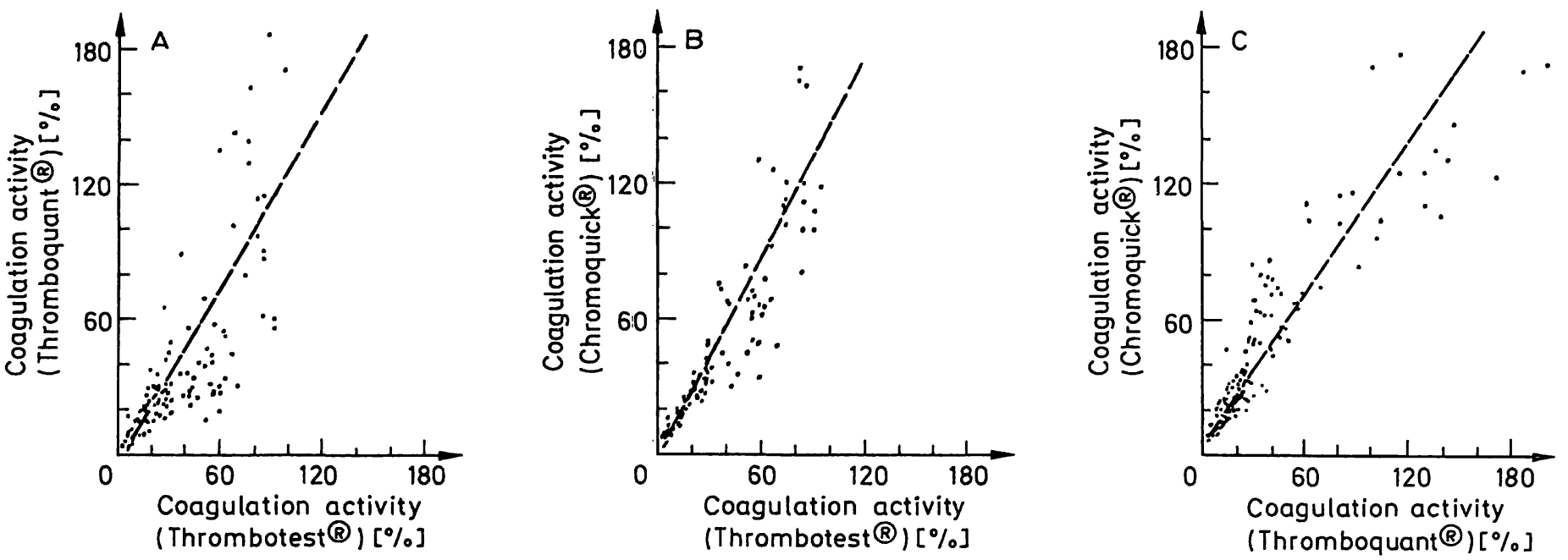

Fig. 2. Comparison of Thrombotest coagulation activity assayed by photometric and coagulometric methods.
A: Thromboquant ${ }^{\infty}$ and Thrombotest ${ }^{\text {to }}$;
B: Chromoquick ${ }^{\circledR}$ and Thrombotest ${ }^{\oplus ;}$
C: Chromoquick and Thromboquant ${ }^{\oplus}$.

Tab. 5. Correlation between photometric and coagulometric methods. Correlation coefficient ( $r$ ) and orthogonal regression of the relation $y=a+b \cdot x$ for various ranges of Thrombotest coagulation activity. CQm: Chromoquick ${ }^{\mathfrak{a}}$ results after modification of the Behring computer program (see text), CQ: Chromoquick ${ }^{(t)}$, TQ: Thromboquant ${ }^{(t)}$.

\begin{tabular}{|c|c|c|c|c|c|c|c|c|c|c|c|c|c|c|c|c|}
\hline \multirow{2}{*}{$\begin{array}{l}\text { Methods } \\
y / x\end{array}$} & \multicolumn{4}{|c|}{ Overall range } & \multicolumn{4}{|c|}{ Thrombotest: $3-20 \%$} & \multicolumn{4}{|c|}{ Thrombotest: $20-50 \%$} & \multicolumn{4}{|c|}{ Thrombotest: $50-100 \%$} \\
\hline & $n$ & $\mathrm{r}$ & a & $\mathrm{b}$ & $\mathrm{n}$ & $r$ & a & b & $\mathrm{n}$ & $\mathbf{r}$ & a & b & $\mathrm{n}$ & $r$ & a & b \\
\hline $\begin{array}{l}\text { CQ/Thrombotest } \\
\text { CQm/Thrombotest } \\
\text { TQ/Thrombotest } \\
\text { CQ/TQ }\end{array}$ & $\begin{array}{l}278 \\
152 \\
280 \\
277\end{array}$ & $\begin{array}{l}0.94 \\
0.92 \\
0.86 \\
0.92\end{array}$ & $\begin{array}{l}-5.8 \\
0.71 \\
-7.5 \\
3.8\end{array}$ & $\begin{array}{l}1.58 \\
1.06 \\
1.37 \\
1.12\end{array}$ & $\begin{array}{l}181 \\
120 \\
183 \\
175\end{array}$ & $\begin{array}{l}0.91 \\
0.92 \\
0.78 \\
0.76\end{array}$ & $\begin{array}{l}-0.3 \\
-0.01 \\
-2.0 \\
-5.2\end{array}$ & $\begin{array}{l}1.30 \\
0.99 \\
1.17 \\
1.84\end{array}$ & $\begin{array}{l}54 \\
26 \\
54 \\
72\end{array}$ & $\begin{array}{l}0.81 \\
0.87 \\
0.42 \\
0.66\end{array}$ & $\begin{array}{l}-27.2 \\
9.6 \\
-66\end{array}$ & $\begin{array}{l}0.63 \\
3.63\end{array}$ & $\begin{array}{r}43 \\
6 \\
43 \\
30\end{array}$ & $\begin{array}{l}0.67 \\
0.73\end{array}$ & $\begin{array}{c}-133 \\
-216 \\
8.8\end{array}$ & $\begin{array}{l}4.19 \\
1.00\end{array}$ \\
\hline
\end{tabular}

boquant and Thrombotest ${ }^{\circledR}$ results varied greatly in the three distinct activity ranges. In the normal range the results of the Thromboquant test were much higher than in the Thrombotest ${ }^{\circledR}$. In two patients the percentage Thrombotest activity was estimated by all three methods during three weeks, in which oral anticoagulant therapy was adjusted. As shown in figure 3 the pattern of results with Chromoquick, and to a lesser extent with Thromboquant, reflected the alterations of the Thrombotest ${ }^{\circledR}$ results.

Sensitivity to the concentration of coagulation factors

The sensitivity of the prothrombin time to the vitamin $\mathrm{K}$-dependent clotting factors is different and characteristic for each type of thromboplastin. We therefore examined in vitro the relation between the prothrombin ratio and the concentration of the single factors II, VII, IX and X. The dependence of the prothrombin ratio on factor $\mathrm{V}$ was only measured with Chromo- quick and Thromboquant reagents, because the Thrombotest ${ }^{\circledR}$ reagent is supplied with this factor. The log of the prothrombin ratio is linearly related to the log of single factor concentrations (fig. 4). With respect to the extrinsic coagulation factors, both photometric tests showed the highest sensitivity to factor $\mathrm{V}$, intermediate sensitivity to factor II and $\mathrm{X}$ and the least, but still good sensitivity to factor VII. Fifty percent reduction of factor II, VII or X gave prothrombin-ratio values between 1.2 and 1.3 in all three methods. For factor $\mathrm{V}$, the prothrombin ratio lay between 1.3 and 1.4 with Thromboquant and Chromoquick reagents. These values are well above the normal range of $0.89-1.11$ for Thromboquant (12) and 0.87-1.12 for Chromoquick (24). The sensitivity to the intrinsic factor IX was very low in both tests. The Thrombotest ${ }^{\circledR}$ was nearly equally sensitive to factor II, VII and X and nearly insensitive to factor IX. The three reagents showed approximately equal sensitivity to factor II and X, while the Thrombotest ${ }^{(i)}$ was more sensitive to factor VII than both photometric tests. 

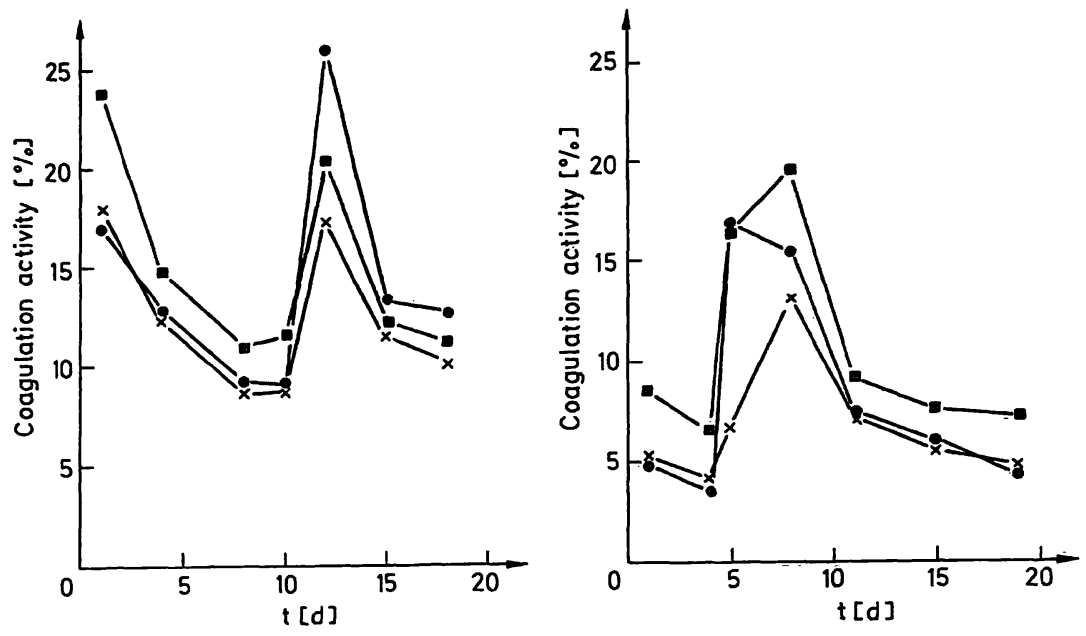

Fig. 3. Thrombotest coagulation activity assayed by photometric and coagulometric methods in two patients during adjustment of oral anticoagulant treatment.

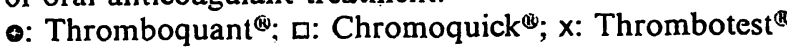
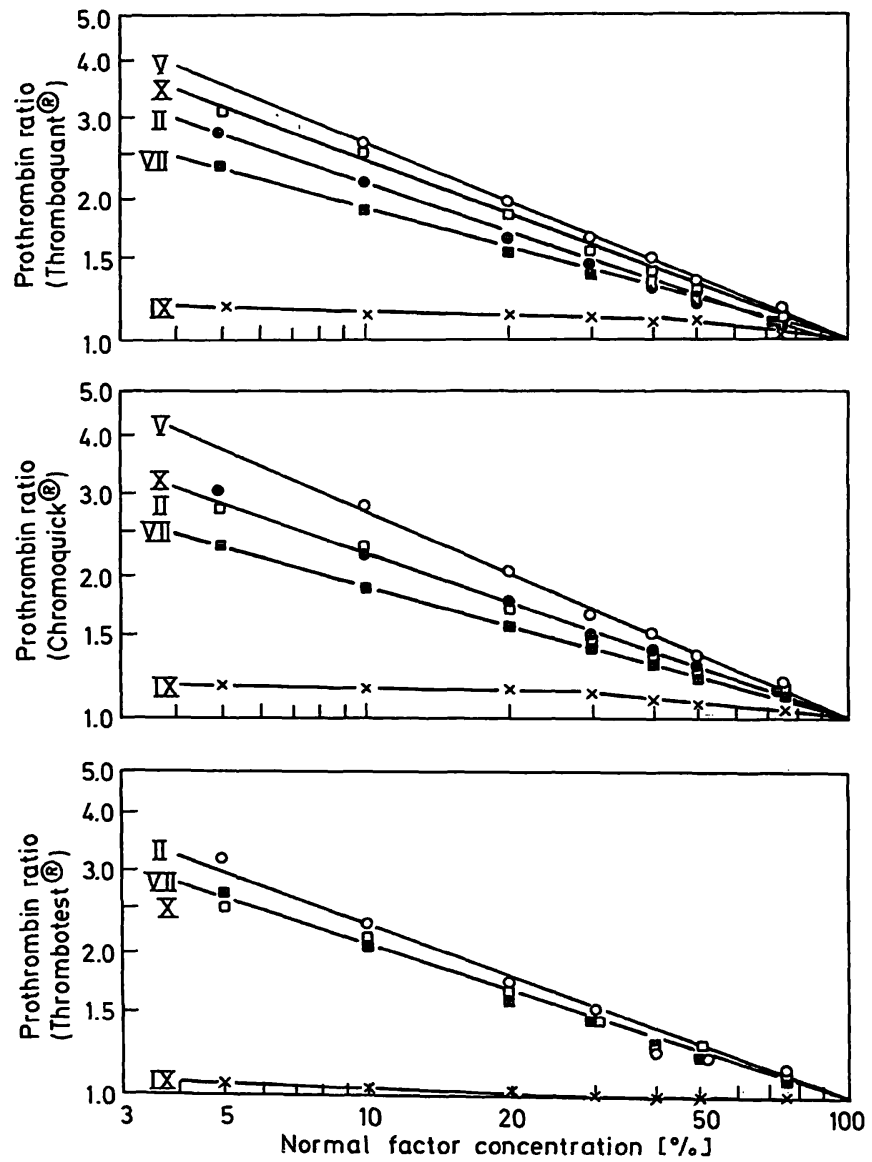

Fig. 4. Relation between the log of single factor concentrations and the log of prothrombin ratio assayed with Chromoquick $^{(1)}$, Thromboquant ${ }^{(0)}$ and Thrombotest ${ }^{+\infty}$ reagents for factor II ( $\square$ ), factor V (O), factor VII ( $\square)$, factor IX $(x)$ and factor $X(0)$.

\section{Reduction of the reagent volume}

The effect of reduction of sample and reagent volume on the results was studied in the interests of economy. Twenty samples with a Thrombotest activity varying from $4 \%$ to $90 \%$ were assayed with Chromoquick reagent in sample volumes ranging from $3 \mu \mathrm{l}$ to $20 \mu \mathrm{l}$, all with a $1 / 10$ sample/reagent ratio. A very high correlation with results in $20 \mu \mathrm{l}$ samples was found for $10 \mu \mathrm{l}$ and higher sample volumes, while the correlation decreased for $5 \mu \mathrm{l}$ and $3 \mu \mathrm{l}$ sample volumes (tab. 6). Pool plasmas and control plasmas with various Thrombotest activities were estimated 10 times with Chromoquick reagent in $5 \mu \mathrm{l}$ and $10 \mu \mathrm{l}$ samples respectively (tab. 7). The intra-assay $\mathrm{CV}$ ranged from $0.4 \%$ for low activities to $5.3 \%$ for high activities

Tab. 6. Correlation of results determined in various sample/ reagent volumes with results in $20 \mu \mathrm{l} / 200 \mu \mathrm{l}$ sample/ reagent volume (sample dilution 11.25).

\begin{tabular}{lll}
\hline $\begin{array}{l}\text { Sample/reagent } \\
\text { volume }(\mu \mathrm{l})\end{array}$ & Sample dilution & $\mathrm{r}$ \\
\hline $15 / 150$ & 11.33 & 0.997 \\
$12 / 120$ & 11.42 & 0.995 \\
$10 / 100$ & 11.50 & 0.998 \\
$5 / 50$ & 12.00 & 0.967 \\
$3 / 30$ & 12.67 & 0.748 \\
\hline
\end{tabular}

Tab. 7. Intra-assay variation of the Chromoquick ${ }^{\oplus}$ test in relation to sample/reagent volumes $(\mu \mathrm{l})$. Mean Thrombotest coagulation activity (\%) of pool plasmas and control plasmas, each determined 10 times, and the resulting $\mathrm{CV}(\%)$. In both series different pool plasmas were employed.

\begin{tabular}{|c|c|c|c|c|c|}
\hline \multirow{2}{*}{$\begin{array}{l}\text { Sample/reagent } \\
\text { volume }(\mu \mathrm{l})\end{array}$} & \multicolumn{2}{|c|}{$10 \mu \mathrm{l} / 100 \mu \mathrm{l}$} & \multicolumn{3}{|c|}{$5 \mu \mathrm{l} / 50 \mu \mathrm{l}$} \\
\hline & mean & CV (\%) & mean & & CV $(\%)$ \\
\hline Pool plasma & 7.5 .5 & 4.0 & 76.9 & & 7.0 \\
\hline Pool plasma & 57.1 & 4.6 & 64.5 & & 5.1 \\
\hline Pool plasma & 32.6 & 1.1 & 48.6 & $\therefore$ & 3.9 \\
\hline Pool plasma & 12.9 & 0.8 & & & \\
\hline $\begin{array}{l}\text { Precichrom } \\
\text { normal }\end{array}$ & 99.8 & 5.3 & 99.7 & & 8.3 \\
\hline $\begin{array}{l}\text { Precichrom } \\
\text { abnormal }\end{array}$ & 10.0 & 0.4 & 7.2 & & 2.1 \\
\hline
\end{tabular}


(mean $2.7 \%$ ), using $10 \mu$ l samples, which corresponds with the precision for $20 \mu \mathrm{l}$ sample volume (tab. 3). On the other hand, the CV ranged from $2.1 \%$ to $8.3 \%$ (mean $5.3 \%$ ) for $5 \mu \mathrm{l}$ samples. Both findings indicate that $10 \mu \mathrm{l} / 100 \mu \mathrm{l}$ sample/reagent is the smallest volume configuration, which yields results comparable to the $20 \mu \mathrm{l} / 200 \mu \mathrm{l}$ protocol.

\section{Discussion}

We wished to evaluate the possibility of replacing the traditional Thrombotest ${ }^{1}$ clotting method by an automated chromogenic substrate test, in order to reduce the workload of prothrombin time tests, which are performed mostly for the control of oral anticoagulant therapy. In addition to using INR units, we therefore also expressed the results of the chromogenic tests in percentage Thrombotest coagulation activity, which is customary in our hospital, in order to avoid change of the therapeutic reference values.

Both assays of prothrombin time using chromogenic substrates can be easily automated on a Cobas Bio ${ }^{(i)}$ analyser, provided arrangements are made to maintain the reagent temperature on $37^{\circ} \mathrm{C}$. Keeping the reagent longer than two hours on $37^{\circ} \mathrm{C}$ is not advisable, owing to the limited stability of both reagents at that temperature. Thus, for stat tests the reagent should be maintained at $25^{\circ} \mathrm{C}$ within one working day or at $4{ }^{\circ} \mathrm{C}$ for longer periods.

Chromogenic substrate tests have several advantages over coagulometric tests. Because the thrombin activity is estimated by photometric measurement of the reaction product, these assays can be automated more easily on common clinical-chemistry analysers. Secondly, in automated photometric prothrombin time tests, smaller sample volumes are needed than in coagulometric tests. We found that reduction of the sample volume on a Cobas $\mathrm{Bio}^{\oplus}$ analyser to $10 \mu \mathrm{l}$ did not change the precision of the Chromoquick test or the correlation with the results of the test performed with $20 \mu \mathrm{l}$ sample volume. Also in the Thromboquant test only $12 \mu$ l of plasma are employed, whereas the Thrombotest ${ }^{\oplus}$ takes $50 \mu$ l of whole blood in the macro Lode device.

Chromogenic prothrombin time assays are not sensitive to abnormalities in the concentration or nature of fibrinogen, which is the substrate in coagulometric methods $(12,24,25)$. Moreover, interference with the conversion of fibrinogen to fibrin by fibrin split products, which occur in disseminated intravascular coagulation and thrombolytic therapy, can prolong the clotting time considerably, although the generation of thrombin is not affected. In such situations, the pho- tometric assay, which uses a constant concentration of an artificial substrate, is little influenced (24). Therefore, chromogenic assays are more useful for the evaluation of coagulation pathways independent of the conversion of fibrinogen to fibrin. Plasma samples containing bilirubin concentrations up to 300 $\mu \mathrm{mol} / \mathrm{l}$, haemoglobin concentrations up to $5 \mathrm{~g} / 1$ or chylomicrons produce no interference with the photometric prothrombin time assay (24).

In photometric assays a better precision is altained than in coagulometric assays $(12,26,27)$. In our study the inter-assay $\mathrm{CV}$ of the prothrombin time amounted to $2.0 \%$ or less in the Chromoquick test and $4.2 \%$ or less in the Thromboquant test. Values for the interassay $\mathrm{CV}$ of the prothrombin time not exceeding 3.4\% (24) and $2.6 \%$ (26) have been reported for the Chromoquick test and not higher than $2.0 \%(12,25)$ for the Thromboquant test. These, as well as our results, indicate that both photometric prothrombin time assays possess good between-assay reproducibility. The Chromoquick reagent gave a somewhat better precision at all coagulation activity levels than the Thromboquant reagent. With an automated chromogenic substrate method, many tests per hour can be performed by one technician. Assuming that one assay takes $4 \mathrm{~min}$ by the clotting method, 90 tests per hour can be done on a 6-channel Lode ${ }^{\text {ai }}$ coagulometer. With a Cobas Bio ${ }^{10}$ analyser, it takes $6 \mathrm{~min}$ for a run of 29 tests and one technician can perform 290 tests per hour. A disadvantage of photometric tests is that samples must be centrifugated, while the Thrombotest $^{\llbracket}$ can be done in whole blood, but the result can be affected by an aberrant haematocrit, and by the presence of bilirubinaemia, lipidaemia and haemolysis.

Values of the Thrombotest activity assayed with Chromoquick reagent correlated well in various activity ranges with the Thrombotest activity assayed by the clotting method. However, when the prothrombin time was estimated with the standard calculation program, orthogonal regression demonstrated a deviation of the percentage Thrombotest results by both methods. With a modified calculation program, in which the mixing time was excluded from the prothrombin time, good conformity between Thrombotest $^{\circledR}$ and Chromoquick results was attained, particularly in the therapeutic activity range. Correlation as well as orthogonal regression indicated notable deviations between the percentage Thrombotest results by the Thromboquant and Thrombotest ${ }^{19}$ methods outside the therapeutic region.

A possible explanation for this finding could be that the ISI value used for the Thromboquant reagent was 
not sufficiently accurate, because good correlation between values for prothrombin time by the Thromboquant and coagulometric methods has been reported $(12,13)$. Otherwise, unsatisfactory agreement between INR results of two different prothrombin time assays has been mentioned recently, suggesting that the introduction of INR units may not have solved the comparability problems for all types of thromboplastins (28). In that study, results with Thrombotest ${ }^{\boxplus}$ reagent were also compared with the results of an automated coagulometric test based on thromboplastin from rabbit brain. Our results confirm that both photometric tests are well suited for monitoring oral anticoagulant therapy, as previously described for Thromboquant (11) and Chromoquick $(24,26)$. Both reagents can be applied to plasma samples from patients under heparin therapy during conversion to oral anticoagulation. In vitro experiments indicated that Thromboquant is nearly insen- sitive to heparin up to a concentration of at least 0.8 $\mathrm{USP} / \mathrm{ml}$ plasma (11) and Chromoquick up to 1.0 $\mathrm{USP} / \mathrm{ml}$, due to the presence of added heparin antagonist $(15,27)$.

The sensitivity of both reagents to the individual clotting factors II, V, VII and X ist good, as was demonstrated by in vitro experiments. Both photometric tests showed comparable sensitivities, while the Thrombotest ${ }^{\oplus}$ reagent was more sensitive to factor VII. The sensitivity of the photometric reagents is suitable for these tests of overall clotting ability, as well as the measurement of individual clotting factors in one-stage assays, which require much less factordeficient plasma than a clotting method. It should be noted that for both chromogenic assays the highest sensitivity was found against factor V deficiency. This could be a disadvantage when monitoring oral anticoagulation, since acquired factor $\mathrm{V}$ deficiencies are relatively frequent.

\section{References}

1. Quick, A. J., Stanley-Brown, M. \& Bancroft, F. W. (1935) Am. J. Med. Sci. 190, 501-511.

2. Quick, A. J. (1959) Circulation 19, 92-96.

3. Owren, P. A. (1959) Lancet II, 754-758.

4. Hemker, H. C., Veltkamp, J. J. \& Loelinger, E. A. (1968) Thrombos. Diathes. Haemorrh. (Stuttg.) 19, 346-363.

5. Duckert, F. \& Marbet, G. A. (1977) Schweiz. Rundschau Med. Praxis 66, 293-294.

6. Svenden, L., Blombaeck, B., Blombaeck, M. \& Olsson, P. (1972) Thrombos. Res. 1, 267-278.

7. van Dieijen-Visser, M. P., van Wersch, J. W. J., Brombacher, P. J., Rosing, J., Hemker, H. K. \& van Dieijen, G. (1982) Haemostasis 12, 241-255.

8. Fareed, J., Messmore, H. L., Walenga, J. M. \& Bermes, E. W. (1983) Clin. Chem. 29, 225-236.

9. Paulssen, M. M. P., Kolhorn, A., Rothuizen, J. \& Planje, M. C. (1979) Clin. Chim. Acta. 92, 465-468.

10. Conkie, J. A., McCall, F., Walker, I. D. \& Davidson, J. F. (1984) Haemostasis 14, 307-311.

11. Jonker, J. J. C., Klarenberg, R. A. \& Jilek, F. (1984) In Neue Aspekte der Gerinnungsdiagnostik (Roka, L. \& Spanuth, E., eds.) pp. 59-79, Schattauer Verlag, Stuttgart.

12. Tripodi, A. \& Mannucio Mannuci, P. (1984) Clin. Chem. 30, 1392-1395.

13. Becker, U., Jering, H., Bartl, K. \& Jilek, F. (1984) Clin. Chem. 30, 524-528.

14. Duncan, A., Bowie, E. J. W., Owen jr., C. A. \& Fass, D. N. (1985) Clin. Chem. 31, 835-855.

15. Dati, F., Kolde, H.-J., Heimburger, N. \& Keller, F. (1986) J. Clin. Chem. Clin. Biochem. 24, 877-888.

16. de Metz, M. \& van Wersch, J. W. J. (1987) Haemostasis $17,254-259$.

17. Becker, U. \& Bartl, K. (1984) In: Neue Aspekte der Gerinnungsdiagnostik (Róka, L. \& Spanuth, E., eds.) pp. 17-30, Schattauer Verlag, Stuttgart.

18. Owren, P. A. \& Aas, K. (1951) Scand. J. Clin. Lab. Invest. 3, 201.

19. Kirkwood, T. B. L. (1983) Thromb. Haemostas. 49, $238-$ 244.

20. van den Besselaar, A. M. H. P., Broekmans, A. W. \& Loelinger, E. A. (1986) Ned. Tijdschr. Geneesd. 130, 19751976.

21. Gogstad, G. O., Wadt, J., Smith, P. \& Brynildsrud, T. (1986) Thromb. Haemostas. 56, 178-182.

22. Deming, W. E. (1943) Statistical Adjustment of Data, p. 184, John Wiley and Sons, New York.

23. Cornbleet, P. J. \& Gochman, N. (1979) Clin. Chem. 25, 432-438.

24. Dati, F., Barthels, M., Conard, J., Flückiger, J., Girolami, A., Hänseler, E., Huber, J., Keller, F., Kolde, H.-J., MüllerBerghaus, G., Samama, M. \& Thiel, W. (1987) Thromb. Haemostas. 58, 856-865.

25. Trobisch, H. \& Adam, H.-G. (1984) In: Neue Aspekte in der Gerinnungsdiagnostik (Róka, L. \& Spanuth, E., eds.) pp. $31-57$, Schattauer Verlag, Stuttgart.

26. Keller, F., Huber, J., Dati, F. \& Kochsiek, K. (1987) Lab. Med. 11, 83-90.

27. Francis, C. W., Malone, J. E. \& Marden, V. J. (1985) Am. J. Clin. Pathol. 14, 724-729.

28. von Schenk, H. \& Jacobsson, M.-L. (1987) Clin. Chem. 33, 342.

Dr J. W. J: van Wersch

De Wever Ziekenhuis

Haematologisch Labor

Postbus 4446

NL-6401 CX Heerlen 